\title{
EFFECT OF HEAT TREATMENT ON NANOCLAY DISPERSING IN NATURAL RUBBER
}

\author{
Do Thanh Thanh Son \\ University of Technology, VNU-HCM \\ (Manuscript Received on November $09^{\text {th }}, 2008$, Manuscript Revised December $08^{\text {th }}, 2010$ )
}

ABSTRACT: Nanocomposites of Nanocor ${ }^{\circledR}$ I.30E and natural rubber grade SVR $3 L$ are investigated. The mixing process is conducted by two-roll mill at different conditions. The structures of clay in rubber matrix are characterized by XRD and SAXS. By premixing the material by two-roll mill at room temperature following with treating at high temperature (about $100^{\circ} \mathrm{C}$ ) the interlayers spacing can reach to $5,17 \mathrm{~nm}$ in case of surface heating in an oven and $4.73 \mathrm{~nm}$ and more in case of internal heating in microwave oven. In some cases an exfoliation can be attained.

Keywords: nanocomposite, natural rubber, XRD, SAXS.

\section{INTRODUCTION}

Properties of clay/rubber nanocomposite depend much more on structures of nanoclay in rubber matrix. They may be intercalation, exfoliation or disordered structures or a mixture of them. In general, in natural-clay filled polymers with favorable thermodynamics for nanocomposite formation, the structure is characterized by a coexistence of exfoliated, intercalated and disordered layers. The mixed exfoliated/intercalated structure is intrinsic in MMT-based nanocomposites and originates from the chemical and size inhomogeneities of the MMT layers. This behavior is common for most polymer/MMT nanocomposites, and typically the larger - in lateral size - MMT layers create intercalated tactoids, whereas the smaller layers tend to exfoliate.
Three main factors that affect the dispersing of nanoclay in melt polymer matrix are thermodynamics, diffusion and stress ${ }^{[1]}$.

Thermodynamics is related to the interactions of polymer and modifying agent in organoclay. The change of free energy of mixing process:

$$
\Delta \mathrm{G}=\Delta \mathrm{H}-\mathrm{T} \Delta \mathrm{S} .
$$

In the intercalation process, the conformation entropy of polymer chains decreases when polymer molecules are forced to be confined inside the narrow silicate interlayer. So that high temperature is not favorable to the intercalation. The intercalation occurs when the polymer/clay interactions are more favorable compared to the modifying agent/clay interactions, i.e. $\Delta \mathrm{H}$ is negative. On the other hand, when nanoclay disperses in polymer the entropy of the system increases due to an improved configurational freedom of 
modifying agent, and a favorable enthalpic contribution obtained when the polymer and nanoclay are mixed. High temperature is more favorable to the exfoliation.

Diffusion of polymer chains into interlayer of nanoclay depends on the molecular weight, temperature and resident time. The lower molecular weight, the higher temperature and the higher resident time, the higher efficiency of diffusion is.

The higher stress, the easier dispersion is but the more breaking down of polymer chains. Stress in mixing process depends on temperature, shear rate and viscosity of polymer. To get a good result these factors must be compromised.

Rubber chains are long, their diffusibility are low. Most of nanoclays are prepared for plastics, so modifiers are not suitable to rubber. These are problems of dispersing nanoclay into rubber matrix, especial in exfoliating.

\section{EXPERIMENT}

\subsection{Materials.}

Natural rubber grade SRV 3L is used in this experiment. The nanoclay is Nanomer I $30 \mathrm{E}$ - the product of Nanocor ${ }^{\circledR}$. This is montmorillonite clay modified by octadecylamine. The content of octadecylamine is $25-30 \%$. The compatilizer is SI $69-$ the product of Degussa. The chemical name is Bis(triethoxysilylpropyl)polysulfide.

\subsection{Experimental Equipments and Procedures.}

To enhance the compatibility of clay and rubber SI 69 is used. The weight ratios of SI 69 and clay are 10:100 and 20:100. Clay and SI 69 are blend in a mortar until homogeneous. To facilitate the mixing ethanol can be used. In this case the mixture must be dried after mixing.

The modified clay then blended with rubber. The contents of clay in rubber are 2, 4, 6,8 and $10 \mathrm{phr}$. Two-roll mill is used for blending. The time of blending is about 10 minutes.

The resulted compounds are treated by heating in the oven at $80^{\circ} \mathrm{C}$ in 2 hours or in the microwave oven in $10 ; 15$ minutes.

The structures of nanocomposites are characterized by XRD and SAXS.

\section{RESULTS AND DISCUSSION}

The XRD and SAXS spectra of rubber nanocomposite using I 30E modified by SI 69 in Figure 1 and Figure 2 revealed the disordered structure of nanocomposite. 

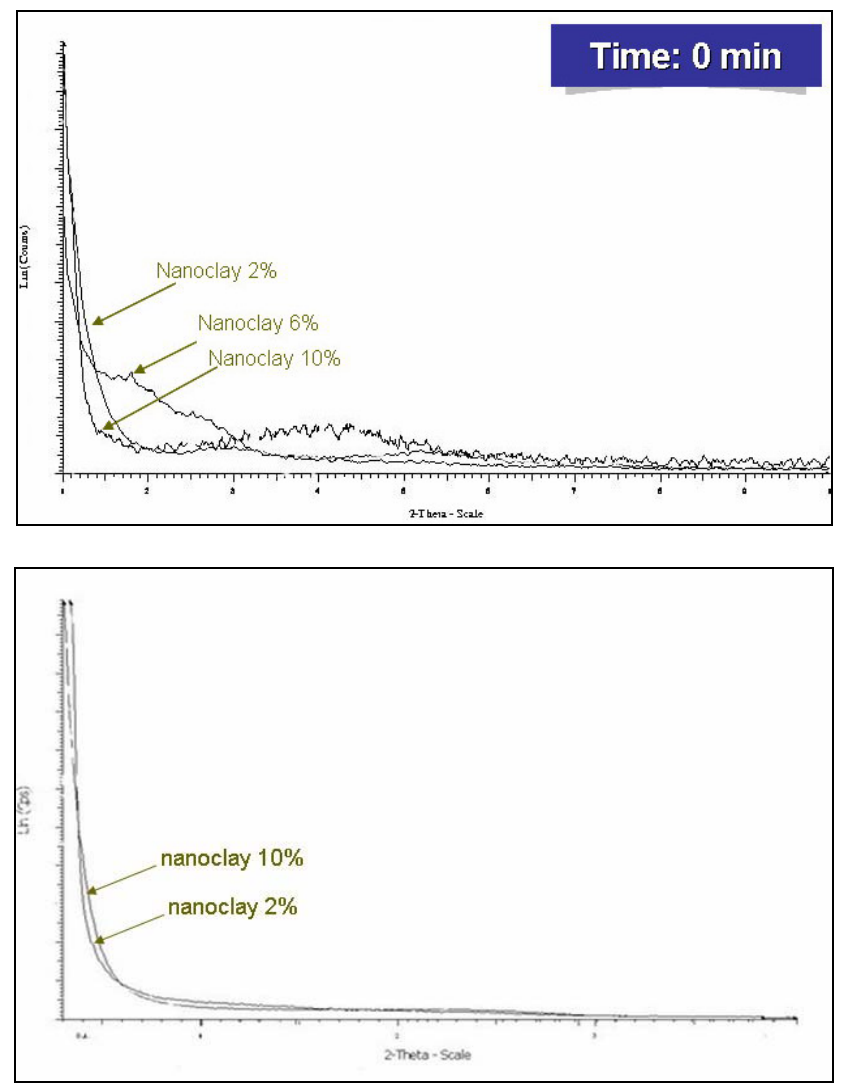

Figure 2. SAXS spectra of nanocomposites

When the ratio of SI 69:Clay increases to 20:100 the spectrum shows the peaks equivalent to the interlayer spacing of 37.12 ; $35.40 ; 34.95 \AA$ compared with $22.59 \AA$ of the original clay. This indicates that when the content of SI 69 increases the interaction between SI 69 and rubber becomes remarkable and benefits the rubber penetration. The results also revealed the effect of nanoclay content in nanocomposite. The higher content of nanoclay, the higher interaction, the more rubber penetration is.

Table 1. Interlayer spacing in chemical treatment

\begin{tabular}{|c|c|c|c|c|c|}
\hline \multicolumn{6}{|c|}{ Interlayer spacing $\AA$} \\
\hline \multirow{2}{*}{ SI69:I30E } & \multicolumn{5}{|c|}{ Nanoclay content (phr) } \\
\cline { 2 - 6 } & 2 & 4 & 6 & 8 & 10 \\
\hline $10: 100$ & - & NA & - & NA & - \\
\hline $20: 100$ & - & 37.12 & 35.40 & 34.95 & NA \\
\hline
\end{tabular}

After heat treatments, structures of nanocomposite change remarkably. They become intercalated structures. The interlayer spacing increases with time of treatment. The existence of two peaks in the XRD spectrum indicates the heterogeneity of the structure

Trang 26 


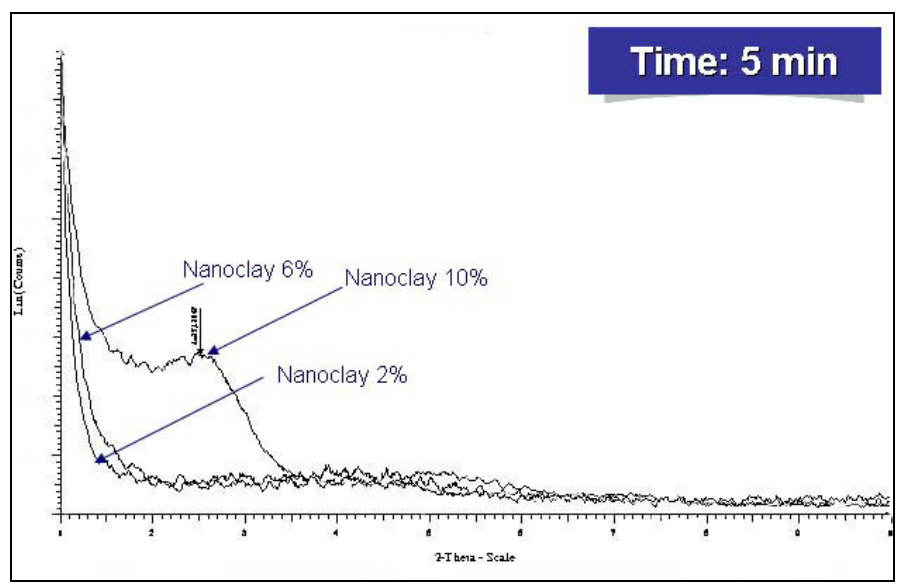

Figure 3. XRD spectra of nanocomposite after treating in microwave oven

By heating in microwave oven, at high heat treatment the larger interlayer spacing of content of nanoclay the structure becomes nanoclay is.

intercalated structure. The interlayer spacing increases with the increasing in time of

Heat generation in microwave heating is treatment and the content of nanoclay. The higher content of nanoclay and/or the longer proportional to the content of nanoclay. The higher content of nanoclay the higher heat generation is.

Table 2. Interlayer spacing in heat treatment Microwave oven - SI69:Clay $=10: 100$

\begin{tabular}{|l|c|c|c|c|c|c|}
\hline \multirow{3}{*}{ Interlayer spacing } & \multicolumn{6}{|c|}{ Nanoclay content (phr) } \\
\cline { 2 - 7 } & \multicolumn{2}{|c|}{2} & \multicolumn{2}{c|}{6} & \multicolumn{2}{c|}{10} \\
\cline { 2 - 7 } & $5 \mathrm{~min}$ & $15 \mathrm{~min}$ & $5 \mathrm{~min}$ & $15 \mathrm{~min}$ & $5 \mathrm{~min}$ & 15 min \\
\hline D1 $(\AA)$ & - & - & - & $\mathbf{4 7 . 3 4}$ & $\mathbf{3 3 . 9 5}$ & $\mathbf{7 7 . 2 1}$ \\
\hline D2 $(\AA)$ & - & - & - & $\mathbf{3 3 . 6 2}$ & - & - \\
\hline
\end{tabular}

Table 3. Heat generation in heat treatment Microwave oven - SI69:Clay $=10: 100$

\begin{tabular}{|c|c|c|c|c|c|c|}
\hline \multirow{2}{*}{} & \multicolumn{6}{|c|}{ Nanoclay content (phr) } \\
\cline { 2 - 7 } & \multicolumn{2}{|c|}{2} & \multicolumn{2}{c|}{6} & \multicolumn{2}{c|}{10} \\
\cline { 2 - 7 } & $5 \mathrm{~min}$ & $15 \mathrm{~min}$ & $5 \mathrm{~min}$ & $15 \mathrm{~min}$ & $5 \mathrm{~min}$ & $15 \mathrm{~min}$ \\
\hline $\mathrm{T}_{\text {ini }}\left({ }^{0} \mathrm{C}\right)$ & $\mathbf{3 0}$ & $\mathbf{3 0}$ & $\mathbf{3 0}$ & $\mathbf{3 0}$ & $\mathbf{3 0}$ & $\mathbf{3 0}$ \\
\hline $\mathrm{T}_{\text {fin }}\left({ }^{0} \mathrm{C}\right)$ & $\mathbf{7 2}$ & $\mathbf{1 2 7}$ & $\mathbf{8 6}$ & $\mathbf{1 1 8}$ & $\mathbf{9 6}$ & $\mathbf{1 2 2}$ \\
\hline
\end{tabular}


By treatment in the hot air oven in 2 hours

at

$80^{\circ} \mathrm{C}$ the structure of nanoccomposite

changes in the same manner as the one treated in microwave oven, but the changes are clearer.

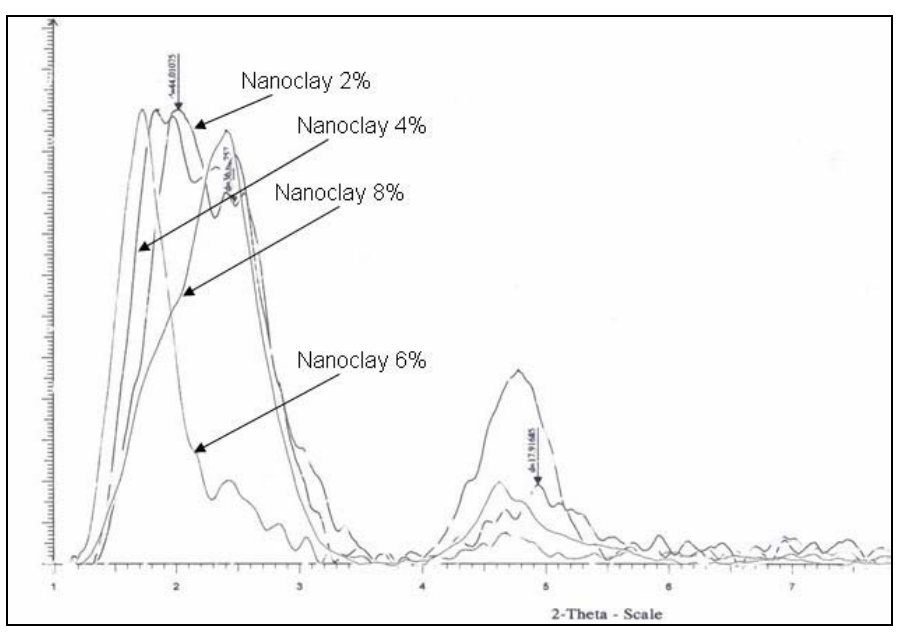

Figure 4. XRD spectra of nanocoposites after treating in hot air oven.

The structures of nanoclay are the higher content of nanoclay the larger heterogeneous. The longer treatment and/or interlayer gallery is.

Table 4. Interlayer spacing in heat treatment Hot air oven - SI69:Clay $=20: 100$

\begin{tabular}{|l|c|c|c|c|c|c|c|c|}
\hline \multirow{3}{*}{ Interlayer spacing } & \multicolumn{8}{|c|}{ Nanoclay content (phr) } \\
\cline { 2 - 10 } & \multicolumn{2}{|c|}{2} & \multicolumn{2}{|c|}{4} & \multicolumn{2}{c|}{6} & \multicolumn{2}{|c|}{8} \\
\cline { 2 - 10 } & $0 \mathrm{~h}$ & $2 \mathrm{~h}$ & $0 \mathrm{~h}$ & $2 \mathrm{~h}$ & $0 \mathrm{~h}$ & $2 \mathrm{~h}$ & $0 \mathrm{~h}$ & $2 \mathrm{~h}$ \\
\hline D1 $(\AA)$ & - & 42.02 & 37.12 & 48.34 & 35.40 & 51.76 & 34.95 & - \\
\hline D2 $(\AA)$ & - & 36.02 & - & 36.09 & - & 36.62 & - & 36.55 \\
\hline
\end{tabular}

The effect of heat treatment indicates that at the first stage by mixing in two-roll mill the structure of nanocomposite mainly is disordered. The shear and peeling distort the structure and the compatibilizer benefits the rubber penetration. In the second stage high temperature is favorable to intercalation and exfoliation.

\section{CONCLUSION}

When mixing in two roll mill the peeling and intercalating process are promoted by shear rates at low temperature. The existence of a compatibilizer promotes the intercalation.

Heat treatment process promotes the intercalation and exfoliation because of increasing in entropy of the system. High temperature is favorable to the gallery expanding and exfoliating process.

\section{Trang 28}


Heat treatment can be used to promote the dispersion of nanoclay in rubber matrix. The process can be conducted in microwave oven or hot air oven. Because of heat degradation of rubber an antioxidant must be added to rubber before treating.

\section{ẢNH HƯởNG CỦA QUÁ TRÌNH XỬ LÝ NHIẸT ĐẾN SỰ PHẨN TÁN CỦA NANOCLAY TRONG CAO SU THIÊN NHIÊN}

\section{Đỗ Thành Thanh Sơn}

Trường Đại học Bách Khoa, ĐHQG-HCM

TÓM TĂT: Nanocomposit của Nanomer ${ }^{\circledR} I 30 E$ và cao su thiên nhiên được chế tạo và nghiên cúu cấu trúc. Quá trình trộn được tiến hành trên máy trộn 2 trục ở các điều kiện khác nhau. Cấu trúc của clay trong nền cao su được khảo sát bằng phổ XRD và SAXS. Bằng cách trộn so bộ trên máy trộn 2 truc, sau đó hồn hợp được xủ lý nhiệt ở nhiệt độ cao (khoảng $100^{\circ} \mathrm{C}$ ) khoảng cách giữa các lớp có thể đạt đến $5,17 \mathrm{~nm}$ khi xử lý trong tủ sấy và đạt đến trên 4,73 nm khi xủ lý trong lò vi sóng. Trong một số truờng hợp có thể có cấu trúc tách lớp.

Tù khóa: Nanocomposit, cao su thiên nhiên, XRD, SAXS.

\section{REFRENCES}

[1]. E. Manias, A. Touny, L. Wu, K. Strawhecker, B. Lu, T.C. Chung Polypropylene/Montmorillonite

Nanocomposites: A Review of Synthetic Routes and Materials Properties. Chemistry of Materials, 13(10), 3516-3523, (2001).

[2]. E. Manias et al, Polymer/inorganic nanocomposites: Opportunities for food packaging applications. Chemistry of Materials, 13(10), 3516, (2001).
[3]. H. R. Dennis, D. L. Hunter et all, Exfoliation- Extruder Effect, Polymer, 42, 9513-9522, (2001).

[4]. H. S. Ku, Mac Robert, E. Siores, J. A. R. Ball, Variable Frequency Microwave Processing of Thermoplastic Composites, Plastics, Rubber and Composites Vol. 29, No. $6,(2000)$.

[5]. E. P. Giannelis, R. Krishnamoorti, E. Manias, Polymer-Silicate Nanocomposites: Model Systems for Confined Polymers and Polymer Brushes, Advances in Polymer Science, Vol.138@), Springer-Verlag Berlin Heidelberg, (1999). 